\title{
Effects of probiotic supplement (Bacillus subtilis and Lactobacillus acidophilus) on feed efficiency, growth performance, and microbial population of weaning rabbits
}

\author{
Thanh Lam Phuoc ${ }^{1}$ and Uttra Jamikorn ${ }^{2, *}$
}

\section{* Corresponding Author: Uttra Jamikorn Tel: +66-8-1444-8300, Fax: +66-2255-3910, E-mail: ck_sof@yahoo.com}

'Department of Animal Sciences, College of Agriculture and Applied Biology, Can Tho University, Can Tho city, Vietnam

2 Department of Animal Husbandry, Faculty of Veterinary Sciences, Chulalongkorn University, Bangkok 10330, Thailand

Submitted Oct 5, 2015; Revised Jan 25, 2016; Accepted Apr 14, 2016
Objective: This study aimed to investigate the effects of single or/and double strains of probiotic supplement on feed efficiency, growth performance, and microbial population in distal gastrointestinal tract (GIT) of weaning rabbits.

Methods: Sixty-four weaning (28 days old) New Zealand White rabbits were randomly distributed into four groups with treatments including: basal diet without probiotic supplement (control) or supplemented as follows: $1 \times 10^{6} \mathrm{cfu} / \mathrm{g} \mathrm{B}$. subtilis (BS group), $1 \times 10^{7} \mathrm{cfu} / \mathrm{g}$ L. acidophilus (LA group), or $0.5 \times 10^{6} \mathrm{cfu} / \mathrm{g}$ B. subtilis plus $0.5 \times 10^{7} \mathrm{cfu} / \mathrm{g}$ L. acidophilus (BL group). During the research, the male and female rabbits were fed separately. Body weight of the rabbits was recorded at 28,42 , and $70 \mathrm{~d}$ of age.

Results: There was an increase $(\mathrm{p}<0.05)$ in body weight gain for the LA group at $42 \mathrm{~d}$. Rabbits fed $B L$ responsed with a greater growth $(\mathrm{p}<0.05)$ and better feed conversion ratio $(\mathrm{p}<0.05)$ than those fed with no probiotic. Digestibility coefficients of dry matter, organic matter, crude protein, neutral detergent fiber, and gross energy were higher $(p<0.05)$ in LA and BL groups than those in the control group. Male rabbits had higher $(\mathrm{p}<0.05)$ Bacilli spp. and Coliformis spp. in the ileum than female rabbits. Rabbits supplemented with BS had greater $(\mathrm{p}<0.05)$ numbers of bacilli in all intestinal segments than those receiving no probiotic, whereas intestinal Lactobacilli populations were greater $(p<0.001)$ in the LA and BL diets compared to control. Average intestinal coliform populations were lowest $(\mathrm{p}<0.05)$ in the rabbits supplemented with LA as compared to those fed the control and BS.

Conclusion: Supplementation of L. acidophilus alone or in combination with B. subtilis at a half of dose could enhance number of gut beneficial bacteria populations, nutrient digestibility, cecal fermentation, feed efficiency, and growth performance, but rabbits receiving only $B$. subtilis alone were not different from the controls without probiotic.

Keywords: Bacillus Subtilis, Lactobacillus Acidophilus, Probiotic, Rabbit

\section{INTRODUCTION}

An intensive system of rabbit production, especially during weaning period, can cause many physiological and environmental stresses. These problems result in concentrating and spreading of enteric pathogens such as Escherichia coli (E. coli), coccidian, and epizootic rabbit enteropathy which have negative effects on growth performance, feed efficiency, and rabbit health status $[1,2]$. Use of antibiotics as growth promoter in livestock farms has been banned by European legislation regarding bacterial resistance [3]. For decades, researches have been conducted to identify alternative substances used for animal production [4]. Supplementation of beneficial normal flora, such as Bacillus subtilis and Lactobacillus acidophilus, in order to improve gut environment, as probiotics appear to be possible alternative feed additives.

\section{www.ajas.info}


Various modes of action of probiotics have been proposed and proved [5]. Currently, there are still few studies of probiotic supplementation in rabbits. Information regarding the effects of probiotics on feed efficiency, growth performance, and microbial population of weaning rabbits are still limited. It is hypothesized that probiotic supplement to weaning rabbits could possibly improve gut-microbial population and digestion resulting in enhanced feed efficiency, body weight gain (BWG), and performance index. This study aimed to investigate the effects of single or/and double strains of probiotic supplement on feed efficiency, growth performance, and microbial population in distal gastrointestinal tract (GIT) of weaning rabbits.

\section{MATERIALS AND METHODS}

Animals and diets

Animal used and protocol were approved by Institutional Animal Care and Use Committee of the Faculty of Veterinary Science, Chulalongkorn University, Thailand. Sixty-four healthy weaning New Zealand White rabbits ( 32 males and 32 females) aged $28 \pm 1$ day were used in this experiment. These rabbits were randomly allocated into four groups with balance in weaning weight and sex as a 2 (male vs female) $\times 4$ (4 diets) factorial design. The male and female rabbits were fed separately in this experiment. Two rabbits were kept in each cage, and there were 32 experimental units in this study. Feeding period lasted for six weeks. All rabbits were housed under natural light and ambient temperature.

A commercial diet for growing rabbits was used as a basal diet (Table 1). Four dietary treatments composed of basal diet without probiotic supplement (control), B. subtilis at $1 \times 10^{6} \mathrm{cfu} /$ $\mathrm{g}$ feed (BS), ii) L. acidophilus at $1 \times 10^{7} \mathrm{cfu} / \mathrm{g}$ feed (LA), or iii) $B$. subtilis and L. acidophilus complex at $0.5 \times 10^{6} \mathrm{cfu} / \mathrm{g}$ feed and

Table 1. Nutrient composition of basal diet used in the experiment

\begin{tabular}{lc}
\hline $\begin{array}{l}\text { Chemical composition } \\
\text { (g/kg of DM unless otherwise noted) }\end{array}$ & \\
\hline Dry matter & 891 \\
Organic matter & 924 \\
Crude protein & 174 \\
Neutral detergent fiber & 390 \\
Acid detergent fiber & 203 \\
Crude fiber & 155 \\
Ether extract & 31.4 \\
Ash & 75.6 \\
Nitrogen free extract & 564 \\
Non fiber carbohydrate & 329 \\
Gross energy (kcal/kg) & 4,398 \\
Digestible energy $(\mathrm{kcal} / \mathrm{kg})$ & 2,747 \\
Metabolizable energy $(\mathrm{kcal} / \mathrm{kg})$ & 2,580 \\
Digestible crude protein & 118 \\
\hline
\end{tabular}

DM, dry matter.
$0.5 \times 10^{7} \mathrm{cfu} / \mathrm{g}$ feed, respectively (BL). Doses of $B$. subtilis and $L$. acidophilus used in this experiment followed the recommendation by SCAN [6,7]. From 28 to 70 days of age (d), the rabbits were offered either the basal diet or the basal diet mixed with probiotics. The basal diet was daily ground to pass through a 5-mm sieve. All treatment diets were daily prepared by mixing the basal diet with probiotic powders (K.M.P Biotech Co., Ltd., Chonburi, Thailand). Feeds and clean water were provided ad libitum.

\section{Sample collection and determination}

Offered and refused feeds were daily weighed to calculate average daily feed intake (ADFI). Feed samples were collected once a week for proximate analyses [8]. Neutral detergent fiber (NDF) and acid detergent fiber (ADF) were analyzed using the method of [9]. The rabbits were weighed at 28, 42, and 70 $\mathrm{d}$ in order to calculate average daily gain. At $63 \mathrm{~d}$, total fecal and urine output of all rabbits in this study were collected daily for a consecutive 5-day period to determine apparent total tract apparent digestibility coefficient of nutrients and nitrogen retention [10]. The urine samples were kept in $10 \%$ sulfuric acid, and placed at $-20^{\circ} \mathrm{C}$ for analysis of nitrogen concentration. Gross energy (GE) in feed and fecal samples was determined by an automatic adiabatic oxygen bomb calorimeter. At $70 \mathrm{~d}$, 32 rabbits were sacrificed by an overdose injection of pentobarbital sodium at 60 to $70 \mathrm{mg} / \mathrm{kg}$ live weight to immediately obtain the intestine. Intestinal contents were subjected for enumeration of Bacillus spp., Lactobacillus spp., and coliform populations. The bacilli were cultured on MYP (Mannitol Egg York Polymyxin-B) agar, under aerobic conditions for $24 \mathrm{~h}$ at $37^{\circ} \mathrm{C}$ [11]. The lactobacilli were cultured in MRS (DeMan, Rogosa, Sharpe) agar, under anaerobic conditions for $48 \mathrm{~h}$ at $37^{\circ} \mathrm{C}$ [12]. Total intestinal coliform was cultured in lauryl triptose broth (LTB), under aerobic conditions for $24 \mathrm{~h}$ at $37^{\circ} \mathrm{C}$ [13]. The $\mathrm{pH}$ of representative digesta contents from fresh cecum was determined using $\mathrm{pH}$ meter (PB 10 model, Mettler Toledo, Goettingen, Germany) and kept at $-80^{\circ} \mathrm{C}$ for measurement of volatile fatty acids (VFA) concentration using gas chromatography.

\section{Calculations}

Nitrogen free extract (NFE) and non fiber carbohydrate (NFC) were calculated by following equations: $\mathrm{NFE}=$ organic matter $(\mathrm{OM})$ - crude protein $(\mathrm{CP})$ - ether extract $(\mathrm{EE})$ - crude fiber $(\mathrm{CF})$ and $\mathrm{NFC}=\mathrm{OM}-\mathrm{CP}-\mathrm{EE}-\mathrm{NDF}$. Metabolizable energy (ME) content was estimated as following equation [14]: ME $(\mathrm{MJ} / \mathrm{kg}$ dry matter $[\mathrm{DM}])=\mathrm{DE}$ (digestible energy) $(0.995-0.048$ digestible crude protein $[\mathrm{DCP}] / \mathrm{DE})$, where $\mathrm{DE}(\mathrm{MJ} / \mathrm{kg} \mathrm{DM})$ $=15.3-0.19 \mathrm{ADF}[15], \mathrm{DCP}(\mathrm{g} / \mathrm{kg} \mathrm{DM})=-34.67+0.876 \mathrm{CP}$ [16]. The ME and DE after estimating were converted from $\mathrm{MJ} / \mathrm{kg} \mathrm{DM}$ to Kcal/kg DM. Total digestible nutrients (\%/DM) $=\mathrm{DCP}+$ digestible nitrogen free extract $(\mathrm{DNFE})+$ digestible crude 
fiber (DCF)+2.25 digestible ether extract (DEE) [17]. Performance index (PI) was calculated as live body weight $(\mathrm{kg}) \times 100 /$ feed conversion ratio (FCR) [18]. Fecal consistency was daily evaluated in the morning. Fecal scores were assigned from 1 to 4, where score 1: normal; 2: soft; 3: mixed soft and liquid; and 4: completely liquid [19]. Fecal consistency index (FCI) was calculated by the following equation: $\mathrm{FCI}=([\mathrm{dE} 1 \times 1]+[\mathrm{dE} 2 \times 2]$ $+[\mathrm{dE} 3 \times 3]+[\mathrm{dE} 4 \times 4]) /(\mathrm{Td} \times 4)$, where $\mathrm{Td}$ is total days of the experiment; $\mathrm{dE} 1, \mathrm{dE} 2, \mathrm{dE} 3$, and $\mathrm{dE} 4$ are the number of days with fecal consistency scoring $=1,2,3$, and 4 , respectively [20]. Daily temperature and humidity were recorded at 9:00 am and 3:00 $\mathrm{pm}$. Temperature-humidity index (THI) was calculated according to [21]. The THI values were classified as following: $<27.8=$ absence of heat stress; 27.8 to $28.9=$ moderate heat stress; 29.0 to $30.0=$ severe heat stress; and $>30.0=$ very severe heat stress.

\section{Statistical analysis}

Experimental data were analyzed as a randomized complete block design, with $2 \times 4$ factorial arrangement of sex and dietary treatments, using the General Linear Model procedures of SAS [22]. Treatment, sex, and interaction between treatment and sex were defined as sources of variation. Significant differences between means were evaluated by Tukey's multiple comparison tests after a significant F-test. These differences were considered to be significant as $\mathrm{p} \leq 0.05$, meanwhile a tendency toward significance was declared at $0.10>p>0.05$. Data were expressed as mean \pm standard error of the mean (SEM), which represents the pooled SEM for the model.

\section{RESULTS}

In this experiment, the average daily temperature and relative humidity were recorded between $26.6^{\circ} \mathrm{C}$ to $33.8^{\circ} \mathrm{C}\left(30.7^{\circ} \mathrm{C}\right.$ $\left.\pm 1.25^{\circ} \mathrm{C}\right)$ and $50 \%$ to $90 \%(66.7 \% \pm 7.77 \%)$, respectively. As the result, the THI was ranged from 26.2 to 30.8 . The average THI value of the experiment was about $29.0 \pm 0.79$.

\section{Feed efficiency and growth performance}

No significant differences were observed on BWG, FCR, and PI when compared between male and female groups (Table 2). However, ADFI from $\mathrm{d} 28$ to $\mathrm{d} 42$ was higher $(\mathrm{p}<0.01)$ and $\mathrm{d} 28$ to $\mathrm{d} 70$ tended to be greater $(\mathrm{p}=0.05)$ in the female group. Between 42 and $70 \mathrm{~d}$, the rabbits received LA and BL had greater $(\mathrm{p}<0.01)$ BW than those fed the control diet. There was a significant increase in BWG $(\mathrm{p}<0.05)$ for the LA group than in the control group at 42 days old. Rabbits supplemented with $\mathrm{BL}$ responded with a greater growth $(\mathrm{p}<0.05)$ and better FCR $(\mathrm{p}<0.05)$ than rabbits supplemented with no probiotic. No differences were found between the groups at 70 days old for ADFI, BWG, and FCR. An increased BWG ( $<<0.05)$ was obtained in rabbits supplemented with either LA or BL when compared to those rabbits in the control from 28 to 70 days old. The BL supplemented group had greater $(\mathrm{p}<0.05)$ PI than the control group. No significant differences were observed when compared between the BS, LA, and BL groups for ADFI, BWG, FCR, and PI at all age. Overall, rabbits supplemented with LA showed the best growth performance among dietary

Table 2. Effects of probiotic supplement on body weight (BW), average daily feed intake (ADFI, g DM/d), body weight gain (BWG, g), feed conversion ratio (FCR, g DM/g gain), and performance index (PI, \%) of weaning rabbits

\begin{tabular}{|c|c|c|c|c|c|c|c|c|c|c|}
\hline \multirow{2}{*}{ Items } & \multicolumn{2}{|c|}{$\operatorname{Sex}^{1)}$} & \multicolumn{4}{|c|}{ Treatments $^{2)}$} & \multirow{2}{*}{ SEM } & \multicolumn{3}{|c|}{$p$-value ${ }^{3)}$} \\
\hline & M & $F$ & Control & BS & LA & $B L$ & & $S$ & $\mathrm{~T}$ & $S \times T$ \\
\hline \multicolumn{11}{|l|}{ BW (g) } \\
\hline $\mathrm{d} 28$ & 476.72 & 518.59 & 497.81 & 497.50 & 496.88 & 498.44 & 22.58 & $<0.001$ & 0.999 & 0.821 \\
\hline$d 42$ & 864.06 & 921.41 & $847.81^{b}$ & $886.56^{\mathrm{ab}}$ & $913.44^{\mathrm{a}}$ & $923.13^{\mathrm{a}}$ & 40.34 & $<0.001$ & 0.006 & 0.225 \\
\hline$d 70$ & $1,566.00$ & $1,659.44$ & $1,506.31^{b}$ & $1,598.19^{\mathrm{ab}}$ & $1,677.75^{\mathrm{a}}$ & $1,668.63^{\mathrm{ab}}$ & 119.17 & 0.038 & 0.032 & 0.746 \\
\hline \multicolumn{11}{|c|}{ d 28-d 42} \\
\hline ADFI & 46.42 & 49.51 & 46.83 & 48.42 & 48.11 & 48.50 & 3.06 & 0.009 & 0.679 & 0.667 \\
\hline BWG & 387.34 & 402.81 & $350.00^{b}$ & $389.06^{\mathrm{ab}}$ & $416.56^{a}$ & $424.69^{a}$ & 44.62 & 0.338 & 0.013 & 0.299 \\
\hline FCR & 1.68 & 1.72 & $1.87^{\mathrm{a}}$ & $1.74^{\mathrm{ab}}$ & $1.62^{\mathrm{ab}}$ & $1.60^{b}$ & 0.20 & 0.711 & 0.029 & 0.117 \\
\hline \multicolumn{11}{|c|}{$d 42-d 70$} \\
\hline ADFI & 79.09 & 82.57 & 79.16 & 79.86 & 82.58 & 81.72 & 6.16 & 0.126 & 0.664 & 0.540 \\
\hline BWG & 701.94 & 738.03 & 658.50 & 711.63 & 764.31 & 745.50 & 91.52 & 0.277 & 0.136 & 0.940 \\
\hline FCR & 3.15 & 3.13 & 3.37 & 3.14 & 3.02 & 3.07 & 0.39 & 0.890 & 0.213 & 0.641 \\
\hline \multicolumn{11}{|c|}{ d 28-d 70} \\
\hline ADFI & 68.20 & 71.55 & 68.39 & 69.38 & 71.09 & 70.64 & 4.55 & 0.050 & 0.632 & 0.587 \\
\hline BWG & $1,089.28$ & $1,140.84$ & $1,008.50^{b}$ & $1,100.69^{a b}$ & $1,180.88^{a}$ & $1,170.19^{a}$ & 124.10 & 0.253 & 0.041 & 0.768 \\
\hline FCR & 2.63 & 2.63 & 2.85 & 2.65 & 2.53 & 2.54 & 0.27 & 0.995 & 0.052 & 0.446 \\
\hline $\mathrm{Pl}$ & 60.44 & 63.50 & $53.43^{b}$ & $60.74^{\mathrm{ab}}$ & $66.75^{\mathrm{ab}}$ & $66.96^{\mathrm{a}}$ & 9.62 & 0.379 & 0.033 & 0.508 \\
\hline
\end{tabular}

SEM, standard error of the mean.

${ }^{1)} \mathrm{M}$ : male; F: female. ${ }^{2)}$ BS, control diet+B. subtilis; LA, control diet+L. acidophilus; BL, control diet+B. subtilis+L. acidophilus.

${ }^{3)} \mathrm{S}$, sex; $\mathrm{T}$, treatment; $S \times \mathrm{T}$, sex and treatment interaction.

a,b Means in a row with different superscripts are significantly different $(p<0.05), n=8$. 
Table 3. Effects of probiotic supplement on fecal consistency index of weaning rabbits

\begin{tabular}{|c|c|c|c|c|c|c|c|c|c|c|}
\hline \multirow{2}{*}{ Items } & \multicolumn{2}{|c|}{$\operatorname{Sex}^{1)}$} & \multicolumn{4}{|c|}{ Treatments $^{2)}$} & \multirow{2}{*}{ SEM } & \multicolumn{3}{|c|}{ p-value ${ }^{3)}$} \\
\hline & M & $\mathrm{F}$ & Control & BS & LA & $B L$ & & $S$ & $\mathrm{~T}$ & $\mathrm{~S} \times \mathrm{T}$ \\
\hline \multicolumn{11}{|l|}{ Fecal score } \\
\hline d 28-d 35 & 1.89 & 2.17 & 2.36 & 2.07 & 1.91 & 1.79 & 0.41 & 0.073 & 0.063 & 0.480 \\
\hline d 35-d 42 & 1.46 & 1.79 & $2.02^{\mathrm{a}}$ & $1.66^{\mathrm{ab}}$ & $1.46^{b}$ & $1.38^{\mathrm{b}}$ & 0.34 & 0.011 & 0.005 & 0.438 \\
\hline d 28-d 42 & 1.67 & 1.98 & $2.19^{\mathrm{a}}$ & $1.87^{\mathrm{ab}}$ & $1.69^{b}$ & $1.58^{b}$ & 0.33 & 0.017 & 0.008 & 0.575 \\
\hline \multicolumn{11}{|c|}{ Fecal consistency index (FCI) } \\
\hline d 28-d 35 & 0.47 & 0.54 & 0.59 & 0.52 & 0.48 & 0.45 & 0.10 & 0.073 & 0.063 & 0.480 \\
\hline d 35-d 42 & 0.37 & 0.45 & $0.50^{\mathrm{a}}$ & $0.42^{\mathrm{ab}}$ & $0.36^{b}$ & $0.35^{b}$ & 0.08 & 0.006 & 0.013 & 0.307 \\
\hline$d 28-d 42$ & 0.46 & 0.54 & $0.59^{\mathrm{a}}$ & $0.51^{\mathrm{ab}}$ & $0.46^{b}$ & $0.44^{b}$ & 0.09 & 0.013 & 0.009 & 0.524 \\
\hline
\end{tabular}

SEM, standard error of the mean.

${ }^{1)} \mathrm{M}$, male; $\mathrm{F}$, female. ${ }^{2)} \mathrm{BS}$, control diet+B. subtilis; $L A$, control diet+L. acidophilus; $B \mathrm{~L}$, control diet+B. subtilis+L. acidophilus.

${ }^{3)} \mathrm{S}$, sex; $T$, treatment; $S \times T$, sex and treatment interaction.

$a, b$ Means in a row with different superscripts are significantly different $(p<0.05), n=8$.

treatments.

\section{Fecal score and fecal consistency index}

The sex and dietary treatment affected fecal score and FCI (Table 3). Sex appeared to have such effects since female rabbits had higher $(\mathrm{p}<0.05)$ fecal score and FCI than male rabbits at age 35 to 42 and 28 to 42 days. Reduced fecal score and FCI ( $<<0.05)$ were obtained in the rabbits receiving either LA or BL supplement when compared to those receiving commercial diet alone at 35 to 42 and 28 to 42 days old. Rabbits supplemented with BS didn't show any significant effects on fecal score and FCI as compared to the rabbits in other treatments.

\section{Digestibility and nitrogen retention}

No differences were observed on digestibilities between male and female groups (Table 4). The results showed that the digestibility coefficients of DM, OM, CP, NDF, and GE were higher $(\mathrm{p}<0.05)$ in the rabbits supplemented with either LA or BL than in rabbits received with no probiotic supplement. The digestibility of $\mathrm{CF}$ in rabbits received no probiotic was the lowest $(\mathrm{p}<0.05)$ when compared to rabbits supplemented with BS, LA, or BL. No differences were found among the treatment groups on nitrogen balance, but retention nitrogen showed a greater tendency $(\mathrm{p}=0.055)$ in the rabbits fed LA compared to the control rabbits.

\section{$\mathrm{pH}$ and volatile fatty acid production of cecal content} There were no significant shifts in cecal pH, total VFA concentration, and molar proportions of individual VFA among treatments (Table 5). There was an interactive effect $(\mathrm{p}=0.01)$

Table 4. Effects of probiotic supplement on coefficient of total tract apparent digestibility and nitrogen retention of growing rabbits at 9 weeks of age

\begin{tabular}{|c|c|c|c|c|c|c|c|c|c|c|}
\hline \multirow{2}{*}{ Items } & \multicolumn{2}{|c|}{$\operatorname{Sex}^{1)}$} & \multicolumn{4}{|c|}{ Treatments $^{2)}$} & \multirow{2}{*}{ SEM } & \multicolumn{3}{|c|}{$p$-value $e^{3)}$} \\
\hline & M & $\mathrm{F}$ & Control & BS & LA & BL & & $S$ & $T$ & $S \times T$ \\
\hline \multicolumn{11}{|c|}{ Coefficient of total tract apparent digestibility } \\
\hline $\mathrm{OM}$ & 0.68 & 0.68 & $0.66^{b}$ & $0.68^{\mathrm{ab}}$ & $069^{\mathrm{a}}$ & $0.69^{\mathrm{a}}$ & 0.015 & 0.504 & 0.012 & 0.945 \\
\hline$C P$ & 0.70 & 0.70 & $0.68^{b}$ & $0.69^{a b}$ & $0.72^{\mathrm{a}}$ & $0.71^{\mathrm{a}}$ & 0.024 & 0.695 & 0.008 & 0.995 \\
\hline NDF & 0.44 & 0.43 & $0.40^{b}$ & $0.44^{\mathrm{ab}}$ & $0.46^{\mathrm{a}}$ & $0.45^{\mathrm{a}}$ & 0.027 & 0.811 & 0.003 & 0.959 \\
\hline NFE & 0.77 & 0.77 & 076 & 0.77 & 0.77 & 0.77 & 0.021 & 0.757 & 0.533 & 0.736 \\
\hline TDN & 0.54 & 0.55 & 0.52 & 0.54 & 0.57 & 0.56 & 0.039 & 0.400 & 0.057 & 0.727 \\
\hline GE & 0.64 & 0.64 & $0.62^{b}$ & $0.64^{\mathrm{ab}}$ & $0.65^{\mathrm{a}}$ & $0.65^{\mathrm{a}}$ & 0.017 & 0.369 & 0.014 & 0.914 \\
\hline \multicolumn{11}{|c|}{ Nitrogen balance (g/d) } \\
\hline $\mathrm{NI}$ & 2.38 & 2.37 & 2.31 & 2.36 & 2.44 & 2.40 & 0.18 & 0.831 & 0.539 & 0.250 \\
\hline
\end{tabular}

SEM, standard error of the mean; DM, dry matter; OM, organic matter; CP, crude protein; NDF, neutral detergent fiber; CF, crude fiber; EE, ether extract; NFE, nitrogen-free extract; TDN, total digestible nutrients; GE, gross energy; NI, nitrogen intake; FN, fecal nitrogen; UN, urinary nitrogen; RN, retention nitrogen.

${ }^{1)} \mathrm{M}$, male; $F$, female. ${ }^{2)} \mathrm{BS}$, control diet+B. subtilis; $L A$, control diet+L. acidophilus; $B L$, control diet+B. subtilis+L. acidophilus.

3) $S$, sex; T, treatment; $S \times T$, sex and treatment interaction.

a,b Means in a row with different superscripts are significantly different $(p<0.05), n=8$. 
Table 5. Effects of probiotic supplement on cecal pH and volatile fatty acids (VFA) of growing rabbits at 10 weeks of age

\begin{tabular}{|c|c|c|c|c|c|c|c|c|c|c|}
\hline \multirow{2}{*}{ Items } & \multicolumn{2}{|c|}{$\operatorname{Sex}^{1)}$} & \multicolumn{4}{|c|}{ Treatments $^{2)}$} & \multirow{2}{*}{ SEM } & \multicolumn{3}{|c|}{ p-value $e^{3)}$} \\
\hline & M & $\mathbf{F}$ & Control & BS & LA & BL & & $S$ & $\mathrm{~T}$ & $S \times T$ \\
\hline $\mathrm{pH}$ & 6.47 & 6.53 & 6.51 & 6.52 & 6.48 & 6.50 & 0.08 & 0.059 & 0.763 & 0.094 \\
\hline \multicolumn{11}{|c|}{ Cecal VFA concentration (mM) } \\
\hline Total & 42.48 & 41.44 & 39.05 & 41.93 & 44.52 & 42.35 & 3.70 & 0.435 & 0.056 & 0.426 \\
\hline Acetate & 34.77 & 34.64 & 32.92 & 34.50 & 34.58 & 36.82 & 2.67 & 0.888 & 0.060 & 0.252 \\
\hline Propionate & 2.31 & 2.12 & 1.86 & 2.27 & 2.39 & 2.35 & 0.52 & 0.297 & 0.177 & 0.732 \\
\hline Butyrate & 5.39 & 4.68 & 4.26 & 5.16 & 5.31 & 5.41 & 1.02 & 0.062 & 0.130 & 0.058 \\
\hline \multicolumn{11}{|c|}{ Cecal VFA proportions (\%) } \\
\hline Acetate & 82.44 & 83.70 & 84.39 & 83.11 & 83.03 & 81.76 & 1.97 & 0.085 & 0.099 & 0.066 \\
\hline Propionate & 5.27 & 5.11 & 4.75 & 5.16 & 5.30 & 5.54 & 1.02 & 0.656 & 0.483 & 0.377 \\
\hline Butyrate & 12.29 & 11.19 & 10.86 & 11.73 & 11.67 & 12.70 & 1.57 & 0.061 & 0.173 & 0.010 \\
\hline
\end{tabular}

SEM, standard error of the mean.

${ }^{1)} \mathrm{M}$, male; F, female. ${ }^{2)} B S$, control diet+B. subtilis; LA, control diet+L. acidophilus; BL, control diet+B. subtilis+L. acidophilus.

${ }^{3)} \mathrm{S}$, sex; $\mathrm{T}$, treatment; $\mathrm{S} \times \mathrm{T}$, sex and treatment interaction.

of sex and treatment on molar proportion of cecal butyrate, the higher value $(\mathrm{p}=0.06)$ was found in the male rabbits.

\section{Gut microbial populations}

The effect of sex and treatment interaction on bacilli, lactobacilli, and coliform population in different segments of intestine was not found in this study (Table 6). The male rabbits had higher $(\mathrm{p}<0.05)$ bacilli and coliforms in the ileum than those in the female rabbits. The female rabbits appeared to have lower numbers of bacilli in ileum $(p<0.01)$ than in cecum and colon. The rabbits supplemented with BS had greater $(\mathrm{p}<0.05)$ numbers of bacilli in ileum and colon than the rabbits received no

Table 6. Effects of probiotic supplement on microbial populations $\left(\log _{10} \mathrm{cfu} / \mathrm{g}\right)$ in different intestinal segments of growing rabbits at 10 weeks of age

\begin{tabular}{|c|c|c|c|c|c|c|c|c|c|c|}
\hline \multirow{2}{*}{ (tems ${ }^{1)}$} & \multicolumn{2}{|c|}{$\operatorname{Sex}^{2)}$} & \multicolumn{4}{|c|}{ Treatments $^{3)}$} & \multirow{2}{*}{ SEM } & \multicolumn{3}{|c|}{$p$-value $e^{4)}$} \\
\hline & $M$ & $F$ & Control & BS & LA & BL & & $S$ & $T$ & $S \times T$ \\
\hline \multicolumn{11}{|l|}{ Bacilli } \\
\hline Ileum & 5.89 & $5.54^{\mathrm{B}}$ & $5.50^{b}$ & $6.07^{\mathrm{a}}$ & $5.54^{\mathrm{ab}}$ & $5.75^{\mathrm{ab}}$ & 0.40 & 0.022 & 0.039 & 0.287 \\
\hline Cecum & 6.15 & $5.95^{\mathrm{A}}$ & $5.64^{b}$ & $6.34^{\mathrm{a}}$ & $6.01^{\mathrm{ab}}$ & $6.21^{\mathrm{a}}$ & 0.31 & 0.076 & 0.001 & 0.844 \\
\hline Colon & 5.80 & $6.00^{A}$ & $5.55^{b}$ & $6.25^{\mathrm{a}}$ & $5.78^{\mathrm{ab}}$ & $6.01^{\mathrm{ab}}$ & 0.36 & 0.122 & 0.005 & 0.754 \\
\hline Average & 5.95 & 5.83 & $5.56^{c}$ & $6.22^{\mathrm{a}}$ & $5.77^{b c}$ & $5.99^{\mathrm{ab}}$ & 0.23 & 0.149 & $<0.001$ & 0.367 \\
\hline SEM & 0.41 & 0.42 & 0.43 & 0.25 & 0.36 & 0.40 & & & & \\
\hline$p$-value & 0.051 & 0.006 & 0.812 & 0.103 & 0.057 & 0.099 & & & & \\
\hline \multicolumn{11}{|l|}{ Lactobacilli } \\
\hline Ileum & 5.33 & 5.38 & $4.69^{b}$ & $4.76^{b}$ & $6.13^{\mathrm{a}}$ & $5.85^{\mathrm{a}}$ & 0.63 & 0.814 & $<0.001$ & 0.300 \\
\hline Cecum & 5.58 & 5.85 & $5.09^{b}$ & $5.37^{b}$ & $6.36^{a}$ & $6.03^{\mathrm{a}}$ & 0.42 & 0.074 & $<0.001$ & 0.422 \\
\hline Colon & 5.57 & 5.66 & $5.01^{c}$ & $5.33^{b c}$ & $6.12^{\mathrm{a}}$ & $6.00^{\mathrm{ab}}$ & 0.51 & 0.627 & $<0.001$ & 0.897 \\
\hline Average & 5.49 & 5.63 & $4.93^{b}$ & $5.16^{b}$ & $6.20^{a}$ & $5.96^{\mathrm{a}}$ & 0.38 & 0.315 & $<0.001$ & 0.625 \\
\hline SEM & 0.80 & 0.61 & 0.46 & 0.59 & 0.52 & 0.45 & & & & \\
\hline$p$-value & 0.618 & 0.100 & 0.218 & 0.097 & 0.586 & 0.699 & & & & \\
\hline \multicolumn{11}{|l|}{ Coliform } \\
\hline lleum & 3.53 & 2.79 & 3.68 & 3.24 & 2.59 & 3.13 & 0.89 & 0.029 & 0.140 & 0.409 \\
\hline Cecum & 3.75 & 3.37 & $4.30^{\mathrm{a}}$ & $3.83^{\mathrm{a}}$ & $2.70^{b}$ & $3.42^{\mathrm{ab}}$ & 0.80 & 0.190 & 0.005 & 0.259 \\
\hline Colon & 3.98 & 3.42 & $4.26^{\mathrm{a}}$ & $4.09^{\mathrm{a}}$ & $2.70^{b}$ & $3.75^{\mathrm{ab}}$ & 0.85 & 0.077 & 0.006 & 0.589 \\
\hline Average & 3.75 & 3.19 & $4.08^{\mathrm{a}}$ & $3.72^{\mathrm{a}}$ & $2.66^{b}$ & $3.43^{\mathrm{ab}}$ & 0.70 & 0.034 & 0.043 & 0.283 \\
\hline SEM & 1.03 & 0.84 & 0.86 & 0.72 & 0.35 & 0.96 & & & & \\
\hline $\mathrm{p}$-value & 0.471 & 0.073 & 0.299 & 0.083 & 0.773 & 0.450 & & & & \\
\hline Total G+ & 6.20 & 6.17 & 5.69 & 6.29 & 6.41 & 6.36 & 0.24 & 0.689 & $<0.001$ & 0.836 \\
\hline $\mathrm{G}^{+} / \mathrm{G}^{-}$ & 1.75 & 2.06 & $1.48^{b}$ & $1.80^{b}$ & $2.43^{\mathrm{a}}$ & $1.93^{b}$ & 0.35 & 0.020 & $<0.001$ & 0.428 \\
\hline
\end{tabular}

SEM, standard error of the mean.

${ }^{1)} \mathrm{G}^{+}$(gram positive) = total gut bacilli and lactobacilli populations; $\mathrm{G}^{-}$(gram negative) $=$total gut coliform population.

${ }^{2)} \mathrm{M}$, male; F, female. ${ }^{3)} B S$, control diet+B. subtilis; $L A$, control diet $+L$. acidophilus; $B L$, control diet $+B$. subtilis $+L$. acidophilus.

4) $S$, sex; $T$, treatment; $S \times T$, sex and treatment interaction.

${ }^{a-c}$ Means in a row with different superscripts are significantly different $(p<0.05), n=8$.

$A, B$ Means in a column with different superscripts are significantly different $(p<0.05), n=16$. 
probiotic. Numbers of bacilli in cecum of rabbits supplemented with $\mathrm{BS}$ or $\mathrm{BL}$ were greater $(\mathrm{p}<0.01)$ than those received no probiotic. The greatest average numbers of bacilli in all segments were observed in the rabbits supplemented with either BS or BL $(\mathrm{p}<0.05)$. Numbers of lactobacilli in ileum, cecum, and average number in all intestinal segments of the rabbits supplemented with LA or BL were greater $(\mathrm{p}<0.001)$ when compared to the rabbits supplemented with no probiotic or BS. Rabbits supplemented with LA had greater number of lactobacilli in colon compared to those in control and BS. No difference was observed for coliform number in ileum among the treatments, but the rabbits supplemented with LA had lower $(\mathrm{p}<0.05)$ coliform number in cecum, colon, and average number in all segments than the rabbits received no probiotic or BS. As the result of increasing beneficial bacteria, mainly lactobacilli, and decreasing of coliform bacteria populations in the intestine, the ratio of Gram-possitive $\left(\mathrm{G}^{+}\right)$to Gramnegative $\left(G^{-}\right)$bacteria was the highest $(p<0.001)$ value in the rabbits received LA treatment compared to other treatments.

\section{DISCUSSION}

The THI at 29.0 as found in this study was the starting point of heat stress for the growing rabbits [21]. There was a strong negative correlation between feed efficiency, BWG, and thermal comfort level of the habitat in the rabbits, whereas there was a positive correlation between THI and rabbit respiration rate [21]. An increase environmental temperature resulted in low BWG, feed efficiency, and high respiratory rate in the animals [21]. The adverse effect of high ambient temperature on rabbit performance might relate to a decrease in feed consumption, animal dehydration, and tissue catabolism [23]. In addition, more energy could be consumed by the increase respiratory frequency. Therefore, low ME left for growth [24].

The BWG was greater and FCR was lower in the rabbits fed diets supplemented with $L$. acidophilus alone or the complex of B. subtilis and $L$. acidophilus compared to the control group demonstrated that $L$. acidophilus had enhanced growth performance of weaning rabbits. These could be due to the greater nutrient digestibility and nitrogen retention in the LA- and BL-supplemented rabbits. The positive effects of probiotic supplement on growth performance and feed efficiency of weaning rabbits were clearly showed in the first two weeks after feeding, while no significant difference was observed in the last four weeks. In the researches of pig, the intestinal microflora becomes stable [25], and normal gut functions have been re-established [26] during two to three weeks of post-weaning period. Therefore, the effect of probiotic supplement on animal growth performance could be expected to be less importance after weaning for 3 weeks [27]. There might be the synergistic effects between $B$. subtilis and $L$. acidophilus since supplementation of mixing B. subtilis and $L$. acidophilus at half dose of each $\left(0.5 \times 10^{6}\right.$ and
$0.5 \times 10^{7} \mathrm{cfu} / \mathrm{g}$ feed) showed similar results in almost all parameters as $L$. acidophilus supplement alone at full dose. Survival $L$. acidophilus was able to release peptides, which could help the growth of typically weakly proteolytic probiotics as Bacillus spp. [28]. Moreover, bacterial activities of Lactobacillus strains were increased after co-culture these bacteria with Bacillus spp.. For this reason, Bacillus spp. could stimulate biosynthetic capacities of Lactobacillus strains [29]. Further investigation should be performed in order to confirm their activities.

The fecal score in current study was used as one parameter to determine fecal status of the weaning rabbits. The lower fecal score in the rabbits supplemented with L. acidophilus or combination of B. subtilis and $L$. acidophilus might relate to the greater total VFA concentration in the intestine of these rabbits (Table 5). VFA provide a powerful driving force for the movement of water and sodium out of the colonic lumen, which leads to reduce moisture content in the feces and therefore a lower fecal score [30]. However, the supplementation of B. subtilis alone did not result in any improvement in the fecal score of weaning rabbits in this study.

The rabbits fed diets supplemented with $L$. acidophilus had greater number of intestinal lactobacilli, which could enhance intestinal hydrolytic enzyme activity in these rabbits resulting in an increase of nutrient digestibility and feed efficiency utilization [31]. Moreover, gut function might have been improved by feeding diet supplemented with $L$. acidophilus due to the increase of lactase and sucrase activities in the small intestinal mucosa [32]. In addition, the lower fecal score and greater intestinal VFA concentration in the rabbits fed diets containing $L$. acidophilus could contribute to the improvement of nutrient digestibility [33]. The higher organic acid concentration in the intestine should be expected to reduce $\mathrm{pH}$ [34], and a low gut $\mathrm{pH}$ has been shown to have a beneficial effect on nutrient digestibility $[35,36]$. However, the diet supplemented with B. subtilis alone did not improve nutrient digestibility and nitrogen retention of weaning rabbits.

The improved tendency of total cecal VFA concentration of the weaning rabbits receiving LA could be due to the greater lactobacilli activity in the cecum [30]. An increase of the total cecal VFA concentration in the rabbits supplemented with $L$. acidophilus was expected to reduce cecal $\mathrm{pH}$, which might exert adverse effect to the intestinal pathogens [34]. In addition, a low gut $\mathrm{pH}$ has been shown to have a beneficial effect on nutrient digestibility [36]. The rabbits fed basal diet supplemented with LA had greater acetic acid concentration in the cecal content than the rabbits fed only basal diet. At the same time, no significant differences were found on cecal concentrations of propionic and butyric acids. This might be due to heterofermentative Lactobacilli strains under strictly anaerobic condition of rabbit cecum leading to produce mainly acetic acid [28].

Lactobacilli are generally absent in GIT of normal adult 
rabbits [37] due to highly acidic environment in the stomach. An increase of the cecal lactobacilli population in the rabbits supplemented with L. acidophilus lead to an increase the cecal acetic acid and total VFA concentration and a reduced intestinal coliform population [38]. Acetic acid has been shown to penetrate into the bacterial cytoplasm resulting in a reduced internal bacterial $\mathrm{pH}$ and collapse the electrochemical proton gradient, leading a bacteriostasis and death of susceptible bacteria such as cecal coliforms [39]. The decrease of the intestinal coliform population could contribute to a reduction of the gastrointestinal problems in the weaning animals [40]. An increase of gram positive and gram negative bacteria ratio in the intestine of LA-fed rabbits suggested that the intestine was predominantly colonized by non-pathogenic bacteria, and toxic substances of intestinal pathogens were inhibited by gut beneficial bacteria.

\section{CONCLUSION}

Supplementation of L. acidophilus alone at $1 \times 10^{7} \mathrm{cfu} / \mathrm{g}$ feed or mixture of B. subtilis at $0.5 \times 10^{6} \mathrm{cfu} / \mathrm{g}$ feed and L. acidophilus at $0.5 \times 10^{7} \mathrm{cfu} / \mathrm{g}$ feed could enhance number of gut beneficial bacteria populations, nutrient digestibility, cecal fermentation, feed efficiency, and growth performance. In addition, gut coliform population and fecal score were reduced in the rabbits supplemented with only L. acidophilus. However, there were no significant effect on growth performance and feed efficien$c y$ in the weaning rabbits supplemented with $B$. subtilis alone at $1 \times 10^{6} \mathrm{cfu} / \mathrm{g}$ feed. The combination of B. subtilis and L. acidophilus at half dose of each showed similar results as the supplementation of L. acidophilus alone at the full dose. These results suggest that the $\mathrm{L}$. acidophilus has potential benefits in terms of probiotic effects in the weaning rabbits.

\section{CONFLICT OF INTEREST}

We certify that there is no conflict of interest with any financial organization regarding the material discussed in the manuscript.

\section{ACKNOWLEDGEMENTS}

Financial support was provided by Chulalongkorn University, Thailand.

\section{REFERENCES}

1.Bovera F, Nizza S, Marono SK, et al. Effect of mannan oligosaccharides on rabbit performance, digestibility and rectal bacterial anaerobic populations during an episode of epizootic rabbit enteropathy. World Rabbit Sci 2010;18:9-16.

2.Licois D, Coudert P, Ceré N, Vautherot JF. Epizootic enterocolitis of the rabbit: review of current research. In: Proceedings of the 7th
World Rabbit Congress, Valencia, Spain; 2000. p. 187-194.

3.Barton MD. Antibiotic use in animal feed and its impact on human health. Nutr Res Rev 2000;13:279-99.

4.Smith DL, Harris AD, Johnson JA, Silbergeld EK, Morris Jr JG. Animal antibiotic use has an early but important impact on the emergence of antibiotic resistance in human commensal bacteria. Proc Natl Acad Sci USA 2002;99:6434-9.

5.Falcão-e-Cunha L, Castro-Solla L, Maertens L, et al. Alternatives to antibiotic growth promoters in rabbit feeding: a review. World Rabbit Sci 2007;15:127-40.

6.SCAN. Opinion of the scientific committee on animal nutrition on the evaluation of the satefy of Calfmix, a micro-organism product. Belgium: Council of the European Union: 2003 [cited 2016 Nov 14]. Available from: https://ec.europa.eu/food/sites/ food/files/safety/docs/animal-feed_additives_rules_scan-old_ report_out121.pdf.

7.SCAN. Report of the scientific committee on animal nutrition on product bioplus $2 \mathrm{~B}^{\star}$ for use as feed additives. Belgium: Council of the European Union; 2000 [cited 2016 Feb 20]. Available from: http://ec.europa.eu/food/fs/sc/scan/out49_en.pdf.

8.AOAC. Official methods of analysis. 18th edn. Association of Official Analytical Chemists Inc., Washington DC: AOAC International; 2005.

9.Van Soest PJ, Robertson JB, Lewis BA. Symposium: carbohydrate methodology, metabolism and nutritional implication in dairy cattle: methods for dietary fiber and nonstarch polysaccharides in relation to animal nutrition. J Dairy Sci 1991;74:3583-97.

10. McDonald P, Edwards RA, Greehalgh JFD, Morgan CA. Digestibility evaluation of foods. In: Animal nutrition. 6th ed. NY, USA: Longman Scientific and Technical; 2002. p. 1-714.

11. ISO 7932. Microbiology of Food and animal Feeding stuffs - Horizontal Method for the enumeration of Presumptive Bacillus cereus Colony - Count Technique at $30^{\circ} \mathrm{C}$. Geneva, Switzerland: International Organization for Standardization; 2004.

12. ISO 15214. Microbiology of Food and Animal Feeding Stuffs Horizontal Method for the Enumeration of Mesophilic Lactic Acid Bacteria - Colony - Count Technique at $30^{\circ} \mathrm{C}$. Geneva, Switzerland: International Organization for Standardization; 1998.

13. ISO 4831. Microbiology of Food and Animal Feeding Stuffs Horizontal Method for the Detection and Enumeration of Coliforms - Most Probable Number Technique. Geneva, Switzerland: International Organization for Standardization; 2006.

14. Maertens L, Perez JM, Villamide M, et al. Nutritive value of raw materials for rabbits: EGRAN Tables 2002. World Rabbit Sci 2002; 10:157-66.

15. Fernández-Carmona J, Soriano J, Pascual JJ, Cervera C. The prediction of nutritive value of rabbit diets from tables of feed composition. In: Proceedings of the 8th World Rabbit Congress, Puebla, Mexico; 2004. p. 818-823.

16. Villamide MJ, Fraga MJ. Prediction of the digestible crude protein and protein digestibility of feed ingredients for rabbits from chemical analysis. Anim Feed Sci Technol 1998;70:211-24. 
17. Cheeke PR, Patton NM, Templeton GS. Rabbits production. 5th ed. Danville, IL: Interstate Printers and Publishers Inc.; 1982.

18. Amber KH, Yakout HM, Hamed RS. Effect of feeding diets containing yucca extract or probiotic on growth, digestibility, nitrogen balance and caecal microbial activity of growing new zealand white rabbits. In: Proceedings of the 8th World Rabbit Congress, Puebla, México; 2004. p. 737-45.

19. Agin TS, Zhu C, Johnson LA, et al. Protection against hemorrhagic colitis in an animal model by oral immunization with isogeneic rabbit enteropathogenic Escherichia coli attenuated by truncating intimin. Infect Immun 2005;73:6608-19.

20. Meyer PM, Vaz Pires A, Bagadlo AR, Correia de Simas JM, Susin I. Addition of probiotic to whole milk or milk replacer and holstein calves performance. Sci Agric 2001;58:215-21.

21. Marai IFM, Ayyat MS, Abd El-Monem UM. Growth performance and reproductive traits at first parity of New Zealand White female rabbis as affected by heat stress and its alleviation under Egyptian condition. Trop Anim Health Prod 2001;33:451-62.

22. SAS. SAS Software User's Guide, release 9.0. NC, USA: SAS Inst. Inc., Cary, NC: SAS Institute Inc.; 2002.

23. Abo-Elezz Z, Salem MN, Abdel-Fattah GA, Yassen AM. Effect of exposure to direct solar radiation on body weight, thermoregulation and reproductive efficiency in the male rabbit. Indian J Anim Sci 1987;57:324-30.

24. Habeeb AA, Aboul-Naga AI, Yousef HM. Influence of exposure to high temperature on daily gain, feed efficiency and blood components of growing male Californian rabbits. Egyptian J Rabbit Sci 1993;3:73-80.

25. Jensen BB. The impact of feed additives on the microbial ecology of the gut in young pigs. J Anim Feed Sci 1998;7:45-64.

26. Pluske JR, Hampson DJ, Williams IH. Factors influencing the structure and function of the small intestine in the weaned pig: a review. Livest Prod Sci 1997;51:215-36.

27. Huang C, Qiao S, Li D, Piao X, Ren J. Effects of Lactobacilli on the performance, diarrhea incidence, VFA concentration and gastrointestinal microbial flora of weaning pigs. Asian-Australas J Anim Sci 2004;17:401-9.

28. Lee YK, Salminen S. Handbook of probiotics and prebiotics. 2nd ed. NJ, USA: John Wiley \& Sons; 2009.

29. Røssland E, Langsrud T, Granum PE, Sørhaug T. Production of antimicrobial metabolites by strains of Lactobacillus or Lactococcus co-cultured with Bacillus cereus in milk. Int J Food Microbiol 2005; 98:193-200.

30. Cummings JH, Macfarlane GT. The control and consequences of bacterial fermentation in the human colon. J Appl Bacteriol 1991; 70:443-59.

31. Fuller R. Probiotics in man and animals. J Appl Bacteriol 1989;66: 365-78.

32. Collington GK, Parker DS, Armstrong DG. The influence of inclusion of either an antibiotic or a probiotic in the diet on the development of digestive enzyme activity in the pig. Br J Nutr 1990;64: 59-70.

33. Giang HH, Viet TQ, Ogle B, Lindberg JE. Growth performance, digestibility, gut environment and health status in weaned piglets fed a diet supplemented with a complex of lactic acid bacteria alone or in combination with Bacillus subtilis and Saccharomyces boulardii. Livest Sci 2012;143:132-41.

34. Högberg A, Lindberg JE. The effect of level and type of cereal nonstarch polysaccharides on the performance, nutrient utilization and gut environment of pigs around weaning. Anim Feed Sci Technol 2006;127:200-19.

35. Canibe N, Jensen BB. Fermented and nonfermented liquid feed to growing pigs: Effect on aspects of gastrointestinal ecology and growth performance. J Anim Sci 2003;81:2019-31.

36. Lyberg K, Lundh T, Pedersen C, Lindberg JE. Influence of soaking, fermentation and phytase supplementation on nutrient digestibility in pigs offered a grower diet based on wheat and barley. Anim Sci 2006;82:853-8.

37. Penney RL, Folk Jr GE, Galask RP, Petzold CR. The microflora of the alimentary tract of rabbit in relation to $\mathrm{pH}$, diet and cold. J Appl Rabbit Res 1986;9:152-6.

38. Jin LZ, Marquardt RR, Baidoo SK. Inhibition of enterotoxigenic Escherichia coli K88, K99 and 987P by the Lactobacillus isolates from porcine intestine. J Sci Food Agric 2000;80:619-24.

39. Eklund T. Organic acids and esters. In: Gould GW, editors. Mechanisms of action of food preservation procedures. NY: Elsevier; 1989. p. 161-200.

40. Oglesbee BL, Jenkins JR. Gastrointestinal diseases. In: Quesenberry KE, Carpenter JW, editors. Ferrets, rabbits, and rodents: clinical medicine and surgery. MO, USA: Elsevier Health Sciences; 2012. p. 193-204. 